\title{
A Short-Term Intervention to Reduce Stress Levels in Workplace for Office Worker at UEFA-The Union of European Football Associations in Nyon/Switzerland
}

\author{
Katia A. Henry¹, Karl J. Neeser ${ }^{2}$, Claus Muss ${ }^{3}$ \\ ${ }^{1}$ Health Management, Collegium Humanum Warsaw Management University, Warsaw, Poland \\ ${ }^{2}$ College Public Health Sciences, Chulalongkorn University, Bangkok, Thailand \\ ${ }^{3}$ School Public Health and Social Work, St Elizabeth University, Bratislava, Slovakia \\ Email: karl.neeser@gmail.com
}

How to cite this paper: Henry, K.A., Neeser, K.J. and Muss, C. (2021) A ShortTerm Intervention to Reduce Stress Levels in Workplace for Office Worker at UEFAThe Union of European Football Associations in Nyon/Switzerland. Open Journal of Preventive Medicine, 11, 211-228.

https://doi.org/10.4236/ojpm.2021.115017

Received: March 25, 2021

Accepted: May 28, 2021

Published: May 31, 2021

Copyright $\odot 2021$ by author(s) and Scientific Research Publishing Inc. This work is licensed under the Creative Commons Attribution International License (CC BY 4.0).

http://creativecommons.org/licenses/by/4.0/

\begin{abstract}
Background: Today, according to the $\mathrm{WHO}$, workplace stress is particularly common. Several medical and scientific studies have shown that workplace stress can have a serious impact on overall health, a triggering or aggravating factor for many diseases and pathological conditions. This study was conducted to investigate the effects of a stress-reducing eight-week workshop and online messages campaign on office workers. Methods: To collect data of this quasi-experimental study with pre- and post-test, DASS-21 (Depression Anxiety Stress Scale) was used (only part stress; 14 items). For eligible samples, stress-reducing workshops and online messages were held for 8 weeks by a specialist. Data were analyzed using SPSS version 20. Results: Of the 68 participants at the beginning, 43 participants were able to follow up on the 8 -week campaign. The drop of participants must be explained by the sudden Covid-19 situation and the postponement of the UEFA EURO 2020 football activities. Overall, 13 of 14 items of stress perception had a decreased score number from pre-test to the post-test results in participants. The test results revealed that there was a significant difference mean of stress score before and after the participants got the campaign with the p-value less than 0.001 . The mean difference was 4.18. It meant that after the campaign the mean of the stress score decrease was 4.18. Conclusion: The intervention at the workplace of office employees at UEFA, the United European Football Association, has shown that simple specific lifestyle behaviors, wrapped up in weekly workshops and online messages over a period of eight weeks, significantly reduced stress and stress-related conditions in office employees and improved positive dimensions of mental health and stress-related behavior.
\end{abstract}


This campaign can be applicable to office workers of any type of organization or company.

\section{Keywords}

Stress, Stress Management, Office Workers, Workplace, Lifestyle Behaviors

\section{Introduction}

Stress is part of everyday life, it is a reaction of the body to strong mental, physical or psychological demands where the organism mobilizes all available forces and energies to cope with the situation. This mechanism has been programmed into the human genome since time immemorial. Bodies are designed with a set of automatic responses to deal with stress: fight or flight effect. When a person realized that he or she is stressed, they will have a stress response which is a rapid and automatic process [1]. Today's life rhythms and demands are often challenging and require intense physical and psychological efforts in order to be sustained [2]. It affects people differently and individuals differ in their stress vulnerability. The effect of stress includes physiological, emotional, cognitive, and behavioral change [3].

An individual person reacts to physical and mental strain by activating interconnected neuroendocrine circuits. Neuroendocrine circuits governing energy balance and stress regulation [4]. This response allows the body to face and deal with the challenge and re-establish the homeostatic equilibrium. If the individual perceives a harmful stimulus as too intense, or its duration as too long, he may fail coping with it, and incur maladaptation. In this case, the stress response does not resolve into a state of balance (either similar or new, i.e., adapted, compared with the state before stress hits), neuroendocrine parameters remain altered, and illness may ensue [2]. Today, most of the time, the pathophysiological complications of disease arise from stress and the subjects exposed to stress, e.g., those that work or live in stressful environments, have a higher risk of many health disorders. Stress can be either a triggering or aggravating factor for many diseases and pathological conditions [1].

\subsection{Chronic Stress and Health}

Neuroendocrine dysregulation by stress may damage practically all organs and tissues. Chronic stress seems to have an effect on brain structure as it is linked to changes in certain brain areas, consisting of volume variations and physical modifications of neuronal networks [5] [6] and may increase vulnerability to psychological and psychiatric disorders [7]. Chronic stress has an impact on the immune system [8]. Psychological stress can induce the acute phase response commonly associated with infections and tissue damage and increase the levels of circulating cytokines (substances secreted by cells of the immune system) and 
of various biomarkers of inflammation [9]. Diseases whose development has been linked to both stress and inflammation include cardiovascular dysfunctions, diabetes, cancer, autoimmune syndromes and mental illnesses such as depression and anxiety disorders [10]. Chronic stress is a high risk factor for atherosclerosis and refers to the non-specific systemic reaction that occurs when the body is stimulated by various internal and external negative factors over a long period [11]. Furthermore, research has confirmed the correlation between atherosclerosis and cardiovascular events [12]. Stress is a potential contributor to chronic hyperglycemia in type 2 diabetes mellitus (T2DM) and has long been shown to have major effects on metabolic activity [13]. Stress-induced increases in glucose cannot be metabolized properly [14]. Ongoing stress weakens the immune system and the potential for immune cells to control cancers has been recognized for many decades and there is clear evidence that therapeutic blockade of specific immune-suppressive mechanisms is enough to make a real difference in survival for patients with several different advanced cancers [15] [16]. And, last but not least, chronic stress may play a critical role in the manifestation of Alzheimer's disease (AD) and is increasingly recognized as a factor that can influence the development and progression of $\mathrm{AD}$ [17].

Workers' and employees' good health and well-being are vital for workplace competitiveness and productivity, a long life and a high quality of life. In the case of illnesses caused by heightened occupational stress, priority should be given to preventive interventions with the purpose of creating and maintaining work conditions respectful of human physiological, emotional and social needs [18].

\subsection{Stress Management}

Effective techniques for stress management typically include healthy lifestyle behaviors and lifestyle measures favoring relaxation that improve physical health, such as nutrition, exercise, sleep or even regular sun exposure, but may also incorporate strategies that improve cognitive and emotional functioning [19]. Mindfulness practices which originates from practices of Buddhism, enjoysgreat interest from a variety of healthcare and epidemiological researchers [20].

Interventions, such as the mindfulness-based stress reduction provide participants with the opportunity to learn breathing, meditation, body scanning techniques, and gentle, yoga-inspired physical exercises [21] [22]. With practice, individuals learn to process emotions, thoughts, and sensations as they arise. Individuals learn to modify their reflexive conditioning from automatically reacting or worrying about the future to a more adaptive, measured response with greater awareness of the present moment [23] [24]. Randomized controlled trials of healthy lifestyle behaviors and mindfulness-based stress reduction interventions have demonstrated improvements to psychological and physiological processes

with relevance to health outcomes and improved stress management in every day's life [25]. 


\subsection{Stress at Workplace}

Workplace stress is particularly common (WHO, Apr 22, 2020) and work-related stress is a serious occupational health problem [26] [27]. It is the harmful physical and emotional responses that can happen when there is a conflict between job demands on the employee and the amount of control an employee has over meeting these demands. In general, the combination of high demands in a job and a low amount of control over the situation can lead to stress [28] [29]. People spend much of their time at work, and the work environment has a strong impact on psycho-physiological and social wellbeing. Today, stress at work is one of the major costs to companies and countries, deeply affecting productivity [30]. Stress in the workplace can have many origins or come from one single event. Every employee is an individual with his professional and personal lives bringing different factors that may influence their reactions to conditions in the workplace. It is generally believed that some stress is okay, but when stress occurs in amounts that people cannot handle, both mental and physical changes may occur (CCOHS, 2018, [28]). Workplace stress can have a serious impact on overall health [31].

\section{Study Aim/Objective}

The study was conducted to investigate and compare the levels of stress experienced by office employees before and after a short-term stress-reducing intervention and to provide new insights for possible and practical stress-reducing measures.

\section{Methods}

The eight week study, carried out in March/April 2020, is a quasi-experimental study with pre-test and post-test that was approved by the Board of UEFA-the Union of European Football Associations-who wants to reassure their employees that the board is aware of their potential stress level and has decided to share with them on how to reduce stress level in the workplace with the help of an anti-stress campaign onsite. Selected participants are all volunteer (subjects = 68). The campaign was advertised on the UEFA Health Website. Participants were required to be 21 or older, able to complete the eight week workshop/online process, and able to complete study data collection forms online. Participants were excluded if they couldn't guarantee to attend the intervention on a regular basis (minimum seven weeks), were on stress medications, or had previously participated in a stress reduction program (less than 1 year).

The research instrument was an eight week campaign of eight stress-reducing specific workshops and online messages:

1) Drink plenty of water [32] [33];

2) Proper breathing and meditation [34] [35] [36];

3) Keep moving/exercise [37] [38] [39];

4) Sunshine and Vitamin D [40] [41] [42]; 
5) Get enough good sleep [43] [44] [45];

6) No stress when eating a healthy Diet [46];

7) Laughter protects against stress [47] [48];

8) Take time for you/Hobbies [49].

Note: the eight selected stress-reducing intervention topics have all been examined in many studies, were easy and problem-free to carry out, and were well received by the participants (Description/details see Annexe 1).

Stress levels (using questionnaires) were collected at week 0 (pre-test) and week 8 (post-test). To collect data, DASS (Depression, Anxiety, Stress, Scale) questionnaire was used, the international scientific recognized self-report scale designed to measure the negative emotional state of depression, anxiety and stress composed by a 42 -item questionnaire. In the present UEFA study, stress was the only concern, hence, the DASS questionnaire was shortened by disregarding the anxiety and depression parts. The stress scale (14 items) is sensitive to levels of chronic non-specific arousal. It assesses difficulty relaxing, nervous arousal, and being easily upset/agitated, irritable/over-reactive and impatient (Annexe 2). As for working conditions, the Likert scale was used, a psychometric scale commonly involved in research that employs questionnaires to measure attitudes or opinions, widely used as an approach to scaling responses in survey research, where respondents are asked to rate items on a level of five agreements: strongly agree; agree; neutral (neither agree/nor disagree); disagree; strongly disagree (Annexe 2). For statistical analysis, the obtained data were analyzed using SPSS for Windows 20. According to the established normality, paired sample t-test will be used for comparing the results before and after the intervention. The threshold of significance was set at $\mathrm{p}<0.05$.

\section{Results}

The result in Table 1 described the participants' characteristics in week 1 before the health campaign was given to participants, and week 8 , after the health campaign was given to participants. In week 1 , the total participants were 68 . But after 8-week follow up the participants became 43 . The drop of participants can be explained by the sudden Covid-19 situation and the postponement of UEFA EURO 2020 activities. Overall, both in week 1 and week 8, the percentages of participants' characteristics were higher in the same categories, except the length of work. In week 1 and week 8 the percentage of female participants was higher than male participants $(72.1 \%$ and $74.4 \%)$. The highest age percentage was in group 30 to 40 ( $47.1 \%$ and $55.8 \%)$. But the age group 50 to 64 decreased in week 8 until 5\% (16.2\% became 9.3\%). The mean and median height of participants showed the same result in week 1 and week 8 . But for the weight, the mean and median of participants in week 8 were lower than in week 1 . Both in week 1 and week 8 , most of the participants were single $(57.4 \%$ and $58.1 \%)$ and had last education in college or university $(83.8 \%$ and $88.4 \%)$. For the participants' length of work, there were more than half of participants who work less than 1 
Table 1. Participants characteristic in week 1 and week 8.

\begin{tabular}{|c|c|c|c|c|}
\hline \multirow{2}{*}{ Characteristics } & \multicolumn{2}{|c|}{ week $1(n=68)$} & \multicolumn{2}{|c|}{ week $8(n=43)$} \\
\hline & $\mathbf{n}$ & $\%$ & $\mathbf{n}$ & $\%$ \\
\hline \multicolumn{5}{|l|}{ Gender } \\
\hline Female & 49 & 72.1 & 32 & 74.4 \\
\hline Male & 19 & 27.9 & 11 & 25.6 \\
\hline \multicolumn{5}{|l|}{ Age } \\
\hline 20 to 30 & 9 & 13.2 & 5 & 11.6 \\
\hline 30 to 40 & 32 & 47.1 & 24 & 55.8 \\
\hline 40 to 50 & 16 & 23.5 & 10 & 23.3 \\
\hline 50 to 64 & 11 & 16.2 & 4 & 9.3 \\
\hline \multicolumn{5}{|l|}{ Height } \\
\hline Mean \pm SD (Range) & \multicolumn{2}{|c|}{$170.5 \pm 8.2(157.0-189.0)$} & \multicolumn{2}{|c|}{$170.6 \pm 7.7(158.0-185.0)$} \\
\hline Median (Q1-Q3) & \multicolumn{2}{|c|}{$169.0(165.0-169.0)$} & \multicolumn{2}{|c|}{$169.0(165.0-175.0)$} \\
\hline \multicolumn{5}{|l|}{ Weight } \\
\hline Mean \pm SD (Range) & \multicolumn{2}{|c|}{$67.3 \pm 13.2(44.0-107.0)$} & \multicolumn{2}{|c|}{$65.5 \pm 11.4(50.0-97.0)$} \\
\hline Median (Q1-Q3) & \multicolumn{2}{|c|}{$64.0(57.5-64.0)$} & \multicolumn{2}{|c|}{$62.0(56.0-75.0)$} \\
\hline \multicolumn{5}{|l|}{ Civil status } \\
\hline single & 39 & 57.4 & 25 & 58.1 \\
\hline Married & 26 & 38.2 & 17 & 39.5 \\
\hline Divorced & 3 & 4.4 & 1 & 2.3 \\
\hline \multicolumn{5}{|l|}{ Education level } \\
\hline College/University & 57 & 83.8 & 38 & 88.4 \\
\hline High school/apprenticeship & 10 & 14.7 & 5 & 11.6 \\
\hline Elementary school & 1 & 1.5 & 0 & 0 \\
\hline \multicolumn{5}{|l|}{ At UEFA since (yrs.) } \\
\hline$\leq 1$ & 26 & 38.2 & 11 & 25.6 \\
\hline $2-5$ & 23 & 33.8 & 18 & 41.9 \\
\hline $6-10$ & 9 & 13.2 & 6 & 14.0 \\
\hline$\geq 11$ & 10 & 14.7 & 8 & 18.6 \\
\hline \multicolumn{5}{|l|}{ Employment } \\
\hline Full time & 57 & 83.8 & 35 & 81.4 \\
\hline Part time & 11 & 16.2 & 8 & 18.6 \\
\hline
\end{tabular}

year did not participate in week 8. That made the percentage in week 1 was highest in participants who already work in UEFA less than 1 year (38.2\%) while in week 8 was highest in participants who already worked for 2 - 5 years (41.9\%). More than $80 \%$ of participants were full-time employment both in week 1 and week 8 (83.8\% and $81.4 \%)$.

Table 2 reported the participants' working conditions before the health campaign was given. As seen in Table 2, from 43 participants, $44.19 \%$ strongly agreed that the working conditions are very pleasant and the other $44.19 \%$ 
Table 2. Participants working condition before health campaign.

\begin{tabular}{lccccc}
\hline \multicolumn{1}{c}{ Working Condition } & $\begin{array}{c}\text { Strongly } \\
\text { Agree }\end{array}$ & Agree & Neutral & Disagree & $\begin{array}{c}\text { Strongly } \\
\text { Disagree }\end{array}$ \\
\hline $\begin{array}{l}\text { My working conditions are } \\
\text { very pleasant. }\end{array}$ & $19(44.19)$ & $2(4.65)$ & $2(4.65)$ & $19(44.19)$ & $1(2.33)$ \\
My workload in general is heavy. & $14(32.56)$ & $5(11.63)$ & $14(32.56)$ & $10(23.26)$ & $0(0.00)$ \\
I have good colleague support. & $23(53.49)$ & $4(9.30)$ & $10(23.26)$ & $4(9.30)$ & $2(4.65)$ \\
I do not feel any job insecurity. & $15(34.88)$ & $9(20.93)$ & $11(25.58)$ & $6(13.95)$ & $2(4.65)$ \\
I have good work-life balance. & $16(37.21)$ & $13(30.23)$ & $9(20.93)$ & $5(11.63)$ & $0(0.00)$ \\
\hline
\end{tabular}

disagreed. Most of them strongly agree that they had a heavy workload in general (32.56\%), had good colleague support (53.49\%), did not feel any job insecurity (34.88\%), and had good work-life balance (37.21\%).

Table 3 revealed that $39.53 \%$ of participants consider the COVID-19 situation to sometimes prevent them from doing their job correctly and followed by $34.88 \%$ that answered it never. After the participants got the health campaign, $53.49 \%$ of them answered that the campaign sometime will help them to deal better with the stressful situations in the future.

As for stress perception, 13 of 14 items of stress perceptions had an increasing number of participants who answer "never" from pre-test to the post-test result (Table 4). The item "I felt that I was rather touchy" had the same percentage in "never" answer pre and post. But the percentage of participants who often felt that they were rather touchy decreased and moved to "sometime". The important point here, the result showed there were 7 items that no one participant answered "almost always" in the post-test after before in the pre-test there were participants who answered, "almost always". The items were "I tended to overreact situations", "I felt myself getting upset rather easily", "I found myself getting impatient when I was delayed in any way (e.g., lifts, traffic lights, being kept waiting)", "I found it hard to wind down", "I found it difficult to tolerate interruptions to what I was doing", "I was intolerant of anything that kept me from getting on with what I was doing", and "I found myself agitated".

Figure 1 showed the difference stress perception score of participants before and after they got a health campaign. There were 12 participants who had an increased score number in the post-test with the highest increase was 12 in participant number 13. And 2 participants had the same score in pre- and post-test, participants number 2 and 43. The rest of the participants showed that their score of stress perception decreased after they got a health campaign. The highest decrease was in participants number 14 with the difference score 21, followed by numbers 29 and 36 with the different scores 20 and 18 .

The Kolmogorov-Smirnov with Lilliefors Correction Test and Shapiro-Wilk Test to test the normality distribution of difference score of stress perception between pre- and post-test on health campaign showed p-value more than 0.05. It meant the distribution was assumed normal. That was why the analysis of the 
Table 3. Participants opinion about covid-19 and their felling after health campaign.

\begin{tabular}{lcccc}
\hline \multicolumn{1}{c}{ Participants' Opinion } & Never & Sometimes & Often & Almost always \\
\hline $\begin{array}{l}\text { Did the Covid-19 situation in any way prevent you from } \\
\text { doing your job correctly? }\end{array}$ & $15(34.88)$ & $17(39.53)$ & $9(20.94)$ & $2(4.65)$ \\
$\begin{array}{l}\text { Do you think this campaign will help you deal better with } \\
\text { stressful situations in the future? }\end{array}$ & $2(4.65)$ & $23(53.49)$ & $12(27.91)$ & $6(13.95)$ \\
\hline
\end{tabular}

Table 4. Participants stress perception on pre- and post-test on the health campaign.

\begin{tabular}{|c|c|c|c|c|c|c|c|c|}
\hline \multirow[b]{2}{*}{ Items } & \multicolumn{4}{|c|}{ Pre-test } & \multicolumn{4}{|c|}{ Post-test } \\
\hline & Never & Sometime & Often & $\begin{array}{l}\text { Almost } \\
\text { always }\end{array}$ & Never & Sometime & Often & $\begin{array}{l}\text { Almost } \\
\text { always }\end{array}$ \\
\hline $\begin{array}{l}\text { I found myself getting upset by quite } \\
\text { trivial things. }\end{array}$ & $2(4.65)$ & $32(74.42)$ & $8(18.60)$ & $1(2.33)$ & $7(16.28)$ & $26(60.47)$ & $9(20.93)$ & $1(2.33)$ \\
\hline I tended to overreact situations. & $6(13.95)$ & $27(62.79)$ & $9(20.93)$ & $1(2.33)$ & $8(18.60)$ & $28(65.12)$ & $7(16.28)$ & $0(0.00)$ \\
\hline $\begin{array}{l}\text { I found it difficult to relax and } \\
\text { switch off work. }\end{array}$ & $9(20.93)$ & $19(44.19)$ & $14(32.56)$ & $1(2.33)$ & $16(37.21)$ & $23(53.49)$ & $3(6.98)$ & $1(2.33)$ \\
\hline I felt myself getting upset rather easily. & $2(4.65)$ & $8(18.60)$ & $31(72.09)$ & $2(4.65)$ & $9(20.93)$ & $28(65.12)$ & $6(13.95)$ & $0(0.00)$ \\
\hline $\begin{array}{l}\text { I felt that I was using a lot of nervous } \\
\text { Energy. }\end{array}$ & $8(18.60)$ & $18(41.86)$ & $13(30.23)$ & $4(9.30)$ & $14(32.56)$ & $19(44.19)$ & $9(20.93)$ & $1(2.33)$ \\
\hline $\begin{array}{l}\text { I found myself getting impatient } \\
\text { when I was delayed in any way } \\
\text { (e.g., lifts, traffic lights, being kept } \\
\text { waiting). }\end{array}$ & $5(11.63)$ & $18(41.86)$ & $14(32.56)$ & $6(13.95)$ & $17(39.53)$ & $20(46.51)$ & $6(13.95)$ & $0(0.00)$ \\
\hline I felt that I was rather touchy. & $11(25.58)$ & $24(55.81)$ & $7(16.28)$ & $1(2.33)$ & $11(25.58)$ & $27(62.79)$ & $4(9.30)$ & $1(2.33)$ \\
\hline I found it hard to wind down. & $10(23.26)$ & $22(51.16)$ & $8(18.60)$ & $3(6.98)$ & $19(44.19)$ & $21(48.84)$ & $3(6.98)$ & $0(0.00)$ \\
\hline I found that I was very irritable. & $8(18.60)$ & $30(69.77)$ & $4(9.30)$ & $1(2.33)$ & $14(32.56)$ & $23(53.49)$ & $5(11.63)$ & $1(2.33)$ \\
\hline $\begin{array}{l}\text { I found it hard to calm down after } \\
\text { something upset me. }\end{array}$ & $8(18.60)$ & $23(53.49)$ & $9(20.93)$ & $3(6.98)$ & $13(30.23)$ & $24(55.81)$ & $4(9.30)$ & $2(4.65)$ \\
\hline $\begin{array}{l}\text { I found it difficult to tolerate } \\
\text { interruptions to what I was doing. }\end{array}$ & $12(27.91)$ & $24(55.81)$ & $6(13.95)$ & $1(2.33)$ & $17(39.53)$ & $24(55.81)$ & $2(4.65)$ & $0(0.00)$ \\
\hline I was in a state of nervous tension. & $8(18.60)$ & $21(48.84)$ & $12(27.91)$ & $2(4.65)$ & $16(37.21)$ & $22(51.16)$ & $3(6.98)$ & $2(4.65)$ \\
\hline $\begin{array}{l}\text { I was intolerant of anything that } \\
\text { kept me from getting on with } \\
\text { what I was doing. }\end{array}$ & $13(30.23)$ & $22(51.16)$ & $7(16.28)$ & $1(2.33)$ & $17(39.53)$ & $26(60.47)$ & $0(0.00)$ & $0(0.00)$ \\
\hline I found myself agitated. & $10(23.26)$ & $20(46.51)$ & $12(27.91)$ & $1(2.33)$ & $12(27.91)$ & $29(67.44)$ & $2(4.65)$ & $0(0.00)$ \\
\hline
\end{tabular}

mean difference between pre- and post-test used a paired-sample t-test.

The test result in Table 5 revealed that there was a significant difference mean of stress score before and after the participants got a health campaign with the p-value less than 0.001 . The mean difference was 4.18 . It meant after the participants got a health campaign the mean of the stress score decrease 4.18. 


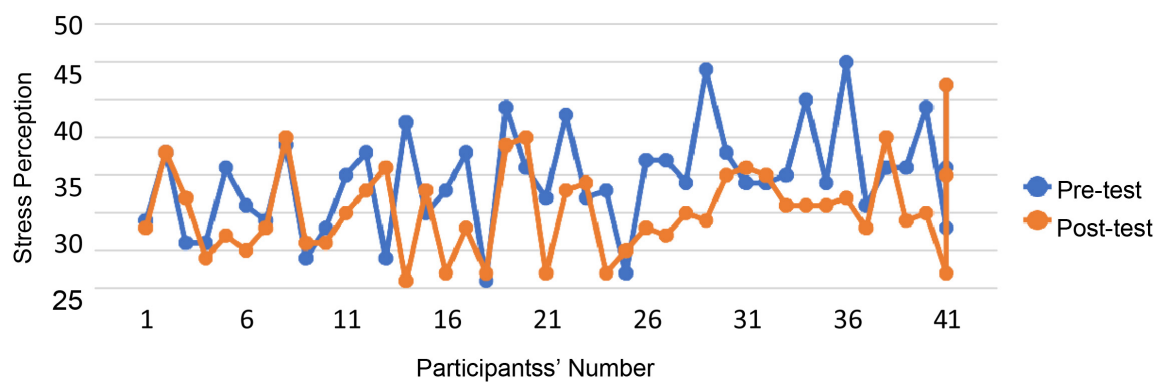

Figure 1. The difference stress perception score of participants on pre- and post-test on the health campaign.

Table 5. Paired-sample t-test stress perception between pre- and post-test health campaign.

\begin{tabular}{ccccccccc}
\hline Variable & & Mean & N & Std. Dev & Mean Difference & T & df & P-value \\
\hline \multirow{3}{*}{ Stress perception } & Before & & & & & 3.9 & & \\
& & 29.74 & 43 & 6.95 & 4.18 & 8 & 42 & $<0.001$ \\
& After & 25.56 & 43 & 5.95 & & & & \\
\hline
\end{tabular}

\section{Discussion}

Today, stress has become a recognizable mode of reaction in an increasingly difficult social and collective climate. There is a considerable increase in medico-psychological complaints related to stress and the interest of employers and societies has proportionately increased as a result. The degree of absenteeism in the workplace could be interpreted as an index of stress. Thus, what we are faced with today is, quantitatively, a real increase in stress-related disorders in the professional framework. Whilst, today, treating mental health problems often requires professional medical intervention, the health campaign amongst office workers at UEFA has shown that when it comes to self-care, the process of forming healthy habits and making positive changes to the daily routine, and also improving emotional and physical health as a way to manage and reduce stress, is possible. The more that people take an active role in helping themselves and making positive improvements in their lifestyles, the better their chances of feeling better and staying well.

The present study showed that the intervention of simple daily lifestyle measures significantly reduced stress levels or stress symptoms and could therefore be considered as complementary medicine. The therapeutic effects of comprehensive lifestyle measures, such as drinking enough water, practicing proper breathing and meditation, taking regular exercise, getting enough sleep, not stressing when eating, taking sufficient time to relax, enjoying a social life, getting sufficient levels of natural sun (Vitamin D) or cultivating an exciting hobby, have been confirmed in previous studies, that endorse yoga practice [39], physical exercise [37], meditation [50], or breathing exercises [35]. This study suggests complementary simple and practical daily measures that are also worthy of inclusion in preventive guidelines. 
Regarding the limitation of the study, the heterogeneity of the eight different lifestyle measures makes it difficult to recommend any specific practice. The effect is more likely to be in the sum of all measures and/or in the individual preference for one or the other weekly intervention. It should however be noted that all participants voluntarily took part in the study and were self-motivated to do so.

\section{Conclusion}

The intervention at the workplace of office employees at UEFA, the United European Football Association, has shown that simple stress-specific lifestyle behaviors, wrapped up in weekly workshops and online messages over a period of eight weeks, significantly reduced stress and stress-related conditions in office workers and improved positive dimensions of mental health and stress-related behaviors. The selected stress-reducing topics were easy and problem-free to carry out and were well received by the participants. In this regard, the eight-week stress campaign at UEFA, the Union of European Football Associations in Nyon/ Switzerland, was statistically relevant and successful in its aims. This campaign may be applicable to office workers of any type of other similar organizations or companies. Further studies to ascertain the long-term effects of practicing these simple and practical lifestyle measures and the underlying biological mechanisms leading to their stress reduction effects should be conducted.

\section{Acknowledgements}

The authors' thanks go to UEFA, the Union of European Football Associations, who gave them the opportunity to run this campaign. And last, but not least, the authors don't want to forget all the participants who persevered despite the difficult Corona situation.

\section{Conflicts of Interest}

The authors declare no conflicts of interest regarding the publication of this paper.

\section{References}

[1] Yaribeygi, H., Panahi, Y., Sahraei, H., Johnston, T.P. and Sahebkar, A. (2017) The Impact of Stress on Body Function: A Review. EXCLI Journal, 16, 1057-1072.

[2] Mariotti, A. (2015) The Effects of Chronic Stress on Health: New Insights into the Molecular Mechanisms of Brain-Body Communication. Future Science OA, 1, Article No. FSO23. https://doi.org/10.4155/fso.15.21

[3] Lebois, L.A.M., Hertzog, C., Slavich, G.M., Feldman Barrett, L. and Barsalou, L.W. (2016) Establishing the Situated Features Associated with Perceived Stress. Acta Psychologica, 169, 119-132. https://doi.org/10.1016/j.actpsy.2016.05.012

[4] Ulrich-Lai, Y.M. and Ryan, K.K. (2014) Neuroendocrine Circuits Governing Energy Balance and Stress Regulation: Functional Overlap and Therapeutic Implications. Cell Metabolism, 19, 910-925. https://doi.org/10.1016/j.cmet.2014.01.020 
[5] Lucassen, P.J., Pruessner, J., Sousa, N., Almeida, O.F.X., Van Dam, A.M., Rajkowska, G., et al. (2014) Neuropathology of Stress. Acta Neuropathologica, 127, 109-135. https://doi.org/10.1007/s00401-013-1223-5

[6] McEwen, B.S. Nasca, C. and Gray, J.D. (2016) Stress Effects on Neuronal Structure: Hippocampus, Amygdala, and Prefrontal Cortex. Neuropsychopharmacology, 41, 3-23. https://doi.org/10.1038/npp.2015.171

[7] Blix, E., Perski, A., Berglund, H. and Savic, I. (2013) Long-Term Occupational Stress Is Associated with Regional Reductions in Brain Tissue Volumes. PLoS ONE, 8, e64065. https://doi.org/10.1371/journal.pone.0064065

[8] Dhabhar, F.S. (2014) Effects of Stress on Immune Function: The Good, the Bad, and the Beautiful. Immunologic Research, 58, 193-210.

https://doi.org/10.1007/s12026-014-8517-0

[9] Black, P.H. (2002) Stress and the Inflammatory Response: A Review of Neurogenic Inflammation. Brain, Behavior, and Immunity, 16, 622-653. https://doi.org/10.1016/S0889-1591(02)00021-1

[10] Maydych, V. (2019) The Interplay between Stress, Inflammation, and Emotional Attention: Relevance for Depression. Frontiers in Neuroscience, 13, Article No. 384. https://doi.org/10.3389/fnins.2019.00384

[11] Yao, B.-C., Meng, L.-B., Hao, M.-L., Zhang, Y.-M., Gong, T. and Guo, Z.-G. (2019) Chronic Stress: A Critical Risk Factor for Atherosclerosis. Journal of International Medical Research, 47, 1429-1440. https://doi.org/10.1177\%2F0300060519826820

[12] Steptoe, A. and Kivimäki, M. (2013) Stress and Cardiovascular Disease. Annual Review of Public Health, 34, 337-354. https://doi.org/10.1146/annurev-publhealth-031912-114452

[13] Surwit, R.S., Schneider, M.S. and Feinglos, M.N. (1992) Stress and Diabetes Mellitus. Diabetes Care, 15, 1413-1422. https://doi.org/10.2337/diacare.15.10.1413

[14] Nowotny, B., Cavka, M., Herder, C., Löffler, H., Poschen, U., Joksimovic, L., et al. (2010) Effects of Acute Psychological Stress on Glucose Metabolism and Subclinical Inflammation in Patients with Post-Traumatic Stress Disorder. Hormone and $\mathrm{Me}$ tabolic Research, 42, 746-753. https://doi.org/10.1055/s-0030-1261924

[15] Repaski, E.A., Eng, J. and Hylander, B.L. (2015) Stress, Metabolism and Cancer: Integrated Pathways Contributing to Immune Suppression. The Cancer Journal, 21, 97-103. https://doi.org/10.1097/PPO.0000000000000107

[16] Surman, M. and Janik, M.E. (2017) Stress and Its Molecular Consequences in Cancer Progression. Postępy Higieny i Medycyny Doświadczalnej, 71, 485-499. https://doi.org/10.5604/01.3001.0010.3830

[17] Dong, H. and Csernansky, J.G. (2019) Stress and Its Impact on Alzheimer's Disease. Neurobiology of Stress, 10, Article ID: 100167. https://doi.org/10.1016/j.ynstr.2019.100167

[18] Lassen, A.D., Fagt, S., Lennernäs, M., Nyberg, M., Haapalar, I., Thorsen, A.V., et al. (2018) The Impact of Worksite Interventions Promoting Healthier Food and/or Physical Activity Habits among Employees Working 'Around the Clock' Hours: A Systematic Review. Food \& Nutrition Research, 62, Article No. 1115. https://doi.org/10.29219/fnr.v62.1115

[19] Halouani, N., Turki, M., Ennaoui, R., Aloulou, J. and Amami, O. (2018) La détresse psychologique du personnel médical et paramédical d'anesthésie-réanimation. The Pan African Medical Journal, 29, Article No. 221. https://doi.org/10.11604/pamj.2018.29.221.12189 
[20] Farhang, M., Miranda-Castillo, C., Rubio, M. and Furtado, G. (2019) Impact of Mind-Body Interventions in Older Adults with Mild Cognitive Impairment: A Systematic Review. International Psychogeriatrics, 31, 643-666. https://doi.org/10.1017/S1041610218002302

[21] Kabat-Zinn, J. (1982) An Outpatient Program in Behavioral Medicine for Chronic Pain Patients Based on the Practice of Mindfulness Meditation: Theoretical Considerations and Preliminary Results. General Hospital Psychiatry, 4, 33-47. https://doi.org/10.1016/0163-8343(82)90026-3

[22] Masoumeh, S., Badfar, G., Parizad Nasirkandy, M., Kaikhavani, S., Rahmati, S., Modmeli, Y., et al. (2018) The Effect of Yoga on Stress, Anxiety, and Depression in Women. International Journal of Preventive Medicine, 9, 21. https://doi.org/10.4103/ijpvm.IJPVM_242_16

[23] Shapiro, S.L. (2009) The Integration of Mindfulness and Psychology. Journal of Clinical Psychology, 65, 555-560. https://doi.org/10.1002/jclp.20602

[24] Zhang, Q., Zhao, H. and Zheng, Y. (2019) Effectiveness of Mindfulness-Based Stress Reduction (MBSR) on Symptom Variables and Health-Related Quality of Life in Breast Cancer Patients-A Systematic Review and Meta-Analysis. Supportive Care in Cancer, 27, 771-781. https://doi.org/10.1007/s00520-018-4570-x

[25] Worthen, M. and Cash, E. (2020) Stress Management. StatPearls, Treasure Island. [Internet]

[26] Harvey, S.B., Modini, M., Joyce, S., Milligan-Saville, J.S., Tan, L., Mykletun, A., et al. (2017) Can Work Make You Mentally Ill? A Systematic Meta-Review of Work-Related Risk Factors for Common Mental Health Problems. Occupational and Environmental Medicine, 74, 301-310.

https://doi.org/10.1136/oemed-2016-104015

[27] Navinés, R., Martín-Santos, R., Olivé, V. and Valdés, M. (2016) Work-Related Stress: Implications for Physical and Mental Health. Medicina Clínica (English Edition), 146, 359-366. https://doi.org/10.1016/j.medcle.2016.06.010

[28] Canadian Centre for Occupational Health \& Safety (2018) Annual Report of the Council: Educating Worker, E-Learning. Hamilton, Canada.

[29] Nadinloyi, K.B., Sadeghi, H. and Hajloo, N. (2013) Relationship between Job Satisfaction and Employees Mental Health. Procedia-Social and Behavioral Sciences, 84, 293-297. https://doi.org/10.1016/j.sbspro.2013.06.554

[30] La Torre, G., Sestili, C., Mannocci, A., Sinopoli, A., De Paolis, M., De Francesco, S., et al. (2018) Association between Work Related Stress and Health Related Quality of Life: The Impact of Socio-Demographic Variables: A Cross Sectional Study in a Region of Central Italy. International Journal of Environmental Research and Public Health, 15, Article No. 159. https://doi.org/10.3390/ijerph15010159

[31] Siegrist, J. and Li, J. (2018) Work Stress and the Development of Chronic Diseases. International Journal of Environmental Research and Public Health, 15, Article No. 536. https://doi.org/10.3390/ijerph15030536

[32] Popkin, P.M., D’Anci, K.E. and Rosenberg, I.H. (2010) Water, Hydration and Health. Nutrition Reviews, 68, 439-458. https://doi.org/10.1111/j.1753-4887.2010.00304.x

[33] Krause, E.G., de Kloet, A.D., Flak, J.N., Smeltzer, M.D., Solomon, M.B., Evanson, N.K., et al. (2011) Hydration State Controls Stress Responsiveness and Social Behavior. Journal of Neuroscience, 31, 5470-5476. https://doi.org/10.1523/JNEUROSCI.6078-10.2011

[34] Xiao, M.A., Yue, Z.-Q., Gong, Z.-Q., Zhang, H., Duan, N.-Y., Shi, Y.-T., et al. (2017) 
The Effect of Diaphragmatic Breathing on Attention, Negative Affect and Stress in Healthy Adults. Frontiers in Psychology, 8, Article No. 874. https://doi.org/10.3389/fpsyg.2017.00874

[35] de Looff, P.C., Cornet, L.J.M., Embregts, P.J.C.M., Nijman, H.L.I. and Didden, H.C.M. (2018) Associations of Sympathetic and Parasympathetic Activity in Job Stress and Burnout: A Systematic Review. PLoS ONE, 13, e0205741. https://doi.org/10.1371/journal.pone.0205741

[36] Zaccaro, A., Piarulli, A., Laurino, M., Garbella, E., Menicucci, D., Neri, B., et al. (2018) How Breath-Control Can Change Your Life: A Systematic Review on Psycho-Physiological Correlates of Slow Breathing. Frontiers in Human Neuroscience, 12, Article No. 353. https://doi.org/10.3389/fnhum.2018.00353

[37] Schultchen, D., Reichenberger, J., Mittl, T., Weh, T.R.M., Smyth, J.M., Blechert, J., et al. (2019) Bidirectional Relationship of Stress and Affect with Physical Activity and Healthy Eating. British Journal of Health Psychology, 24, 315-333. https://doi.org/10.1111/bjhp.12355

[38] Matzer, F., Nagele, E., Lerch, N., Vajda, C. and Fazekas, C. (2018) Combining Walking and Relaxation for Stress Reduction-A Randomized Cross-Over Trial in Healthy Adults. Stress Health, 34, 266-277. https://doi.org/10.1002/smi.2781

[39] Davendra, K.T. (2014) Yoga and Health. Indian Journal of Community Medicine, 39, 68-72. https://doi.org/10.4103/0970-0218.132716

[40] Abu-Samak, M.S., AbuRuz, M.E., Masa’Deh, R., Khuzai, R. and Jarrah, S. (2019) Correlation of Selected Stress Associated Factors with Vitamin D Deficiency in Jordanian Men and Women. International Journal of General Medicine, 12, 225-233. https://doi.org/10.2147/IJGM.S198175

[41] Bičíková, M., Dušková, M., Vítků, J., Kalvachová, B., Řípová, D., Mohr, P., et al. (2015) Vitamin D in Anxiety and Affective Disorders. Physiological Reviews, 64, S101-S103. https://doi.org/10.33549/physiolres.933082

[42] An, M., Colarelli, S.M., O’Brien, K. and Boyajian, M.E. (2016) Why We Need More Nature at Work: Effects of Natural Elements and Sunlight on Employee Mental Health and Work Attitudes. PLoS ONE, 11, e0155614. https://doi.org/10.1371/journal.pone.0155614

[43] Choi, D.W., Chun, S.-Y., Lee, S.A., Han, K.-T. and Park, E.-C. (2018) Association between Sleep Duration and Perceived Stress: Salaried Worker in Circumstances of High Workload. International Journal of Environmental Research and Public Health, 15, Article No. 796. https://doi.org/10.3390/ijerph15040796

[44] Furuichi, W., Shimura, A., Miyama, H., Seki, T., Ono, K., Masuya, J. and Inoue, T. (2020) Effects of Job Stressors, Stress Response, and Sleep Disturbance on Presenteeism in Office Workers. Neuropsychiatric Disease and Treatment, 16, 1827-1833. https://doi.org/10.2147/NDT.S258508

[45] Kim, E.-J. and Dimsdale, J.E. (2007) The Effect of Psychosocial Stress on Sleep: A Review of Polysomnographic Evidence. Behavioral Sleep Medicine, 5, 256-278. https://doi.org/10.1080/15402000701557383

[46] Xenaki, N., Bacopoulou, F., Kokkinos, A., Nicolaides, N.C., Chrousos, G.P. and Darviri, C. (2018) Impact of Stress Management Program in Adults with Obesity. Journal of Molecular Biochemistry, 7, 78-84.

[47] Dexter, L., Brook, K. and Frates, E. (2016) The Laughter Prescription-A Tool for Lifestyle Medicine. American Journal of Lifestyle Medicine, 10, 262-267. https://doi.org/10.1177\%2F1559827614550279

[48] Jong, E.Y. (2016) Therapeutic Benefits of Laughter in Mental Health: A Theoretical 
Review. Tohoku Journal of Experimental Medicine, 239, 243-249.

https://doi.org/10.1620/tjem.239.243

[49] Doan, S., Ritchart, A., Perry, N., Chaparro, J.D. and Conway, M. (2017) How Do You Relax When You Are Stressed? A Content Analysis and Infodemiology Study of Stress-Related Tweets. JMIR Public Health Surveill, 3, Article No. e35. https://doi.org/10.2196/publichealth.5939

[50] Ines, K.E., Selfe, T.K., Brown, C.J., Rose, K.M. and Thompson-Heisterman, A. (2012) The Effects of Meditation on Perceived Stress and Related Indices of Psychological Status and Sympathetic Activation in Persons with Alzheimer's Disease and Their Caregivers: A Pilot Study. Evidence-Based Complementary and Alternative Medicine, 2012, Article ID: 927509. https://doi.org/10.1155/2012/927509

[51] Hölzel, B.K., Carmody, J., Vangel, M., Congleton, C., Yerramsetti, S.M., Gard, T., et al. (2011) Mindfulness Practice Leads to Increases in Regional Brain Gray Matter Density. Psychiatry Research: Neuroimaging, 191, 36-43.

https://doi.org/10.1016/j.pscychresns.2010.08.006

[52] Conrad, A., Müller, A., Doberenz, S., Kim, S., Meuret, A.E., Wollburg, E. and Roth, W.T. (2007) Psychophysiological Effects of Breathing Instructions for Stress Management. Applied Psychophysiology and Biofeedback, 32, 89-98.

https://doi.org/10.1007/s10484-007-9034-x

[53] Koo, K.-M. and Kim, C.-J. (2018) The Effect of the Type of Physical Activity on the Perceived Stress Level in People with Activity Limitations. Journal of Exercise Rehabilitation, 14, 361-366. https://doi.org/10.12965/jer.1836164.082

[54] Kuramoto, A.M. (2006) Therapeutic Benefits of Tai Chi Exercise: Research Review. Wisconsin Medical Journal, 105, 42-46.

[55] Woodyard, C. (2011) Exploring the Therapeutic Effects of Yoga and Its Ability to Increase Quality of Life. International Journal of Yoga, 4, 49-54. https://doi.org/10.4103/0973-6131.85485

[56] Cheng, Y.-C., Huang, Y.-C. and Huang, W.-L. (2020) The Effect of Vitamin D Supplement on Negative Emotions: A Systematic Review and Meta-Analysis. Depression and Anxiety, 37, 549-564. https://doi.org/10.1002/da.23025

[57] Nathaniel Mead, M. (2008) Benefits of Sunlight: A Bright Spot for Human Health. Environmental Health Perspectives, 116, A160-A167. https://doi.org/10.1289/ehp.116-a160 


\section{Annexe 1: Description of the Eight Stress-Reducing Intervention Topics, UEFA Campaign}

The eight selected stress-reducing intervention topics have all been examined in many studies, were easy and problem-free to carry out, and were well received by the participants.

For participants' stress perception, the results revealed a significant difference mean of stress score before and after the intervention for most of them. The therapeutic effects of simple and practical lifestyle measures to fight stress, like drinking enough water, proper breathing, regular exercise, enough sleep, no stress when eating, taking sufficient time to relax, enjoying social life, sunbathing (Vitamin D) or cultivate an exciting hobby have been confirmed in many other studies. Overall, there is current evidence for their therapeutic effectiveness.

1) Drinking enough water is a simple measure to specifically prevent stress. Hypernatremia is a common electrolyte problem that is defined as a rise in serum sodium concentration to a value exceeding $145 \mathrm{mmol} / \mathrm{L}$. It is strictly defined as a hyperosmolar condition caused by a decrease in total body water (TBW) relative to electrolyte content [32]. Hypernatremia most often occurs in people who are stressed. Current results, in agreement with previous studies, strongly suggest that acute hypernatremia limits stress responding [33].

2) Slow and deep breathing activates the parasympathetic nervous system. The sympathetic nervous system functions like a gas pedal in a car. It triggers the fight-or-flight response, providing the body with a burst of energy so that it can respond to perceived dangers. The parasympathetic nervous system acts like a brake. When the parasympathetic nervous system is activated, it produces a calm and relaxed feeling in the mind and body [34]. People can learn to trigger their parasympathetic nervous system by slow and deep breathing to immediately reduce their sense of anxiety and stress [35]. The psycho-physiological changes in brain-body interaction observed in most of meditative and relaxing practices rely on voluntary slowing down of breath frequency [34] [51]. Slow breathing techniques seem to interact with the cardio-respiratory system by increasing HRV and RSA, suggesting thus a strong involvement of the parasympathetic nervous system [36] [52].

3) According to many studies, regular exercise works as well as medication for some people to reduce symptoms of stress, and the effects can be long lasting. One vigorous exercise session can help alleviate symptoms for hours, and a regular schedule may significantly reduce stress over time. The benefits of aerobic exercise like walking, running, dancing include an increased heart rate. When your heart rate is accelerated, your body releases endorphins, natural opiates that make people feel good and relaxed [37] [53]. In recent years, several medical and scientific studies on yoga exercises proved it to be very useful in the treatment of stress symptoms [38]. Yoga means the unity of mind and body, which has been used in Eastern Societies since thousands of years ago and has recently received much attention from Western countries [54]. Yoga has an effective role 
in reducing stress as well as beneficial effects on many other health conditions [39] [55].

4) Study after study indicates the direct link between Vitamin D levels and mental health is so strong. A positive association between Vitamin D levels and elevated serum cortisol has been observed [40] [56]. A 2015 review study reports that people with symptoms of stress, anxiety and depression had lower levels of calcidiol, a byproduct of vitamin D breakdown, in their bodies [41]. Today's scientists have come to the recognition that exposure to the ultraviolet radiation (UVR) in sunlight, the natural source of Vitamin D, has beneficial effects on human health. Direct sunlight is a dominant predictor of anxiety and stress; indirect sunlight is a dominant predictor of depressed mood [57]. Exposure to natural elements in the workplace will be positively related to employees' mental health-lower depressed mood, anxiety, stress-and work attitudes like higher job satisfaction and organizational commitment [42].

5) Sleep is important to manage stress. Stress awareness is associated with short sleep duration. Numerous studies focus on the need for stress management to improve sleep. The main finding of these studies is that short sleep duration might be associated with an increased odds ratio for perceived stress compared to adequate sleep duration [43]. A good night's sleep makes people able to tackle the day's stress more easily [44]. When people are tired, they are less patient and more easily agitated, which can increase stress [45].

6) No stress when eating: Avoid dealing with a stressful situation when eating. Enjoying a healthy diet in a quiet environment can reduce the negative effects of stress on our body. A healthy diet, enjoyed in peace, builds a solid, more enduring foundation for our body by reducing oxidation and inflammation [46].

7) Laughter induction initiates the fight-or-flight stress response. However, approximately 20 minutes after laughter, physiological measures such as heart rate, blood pressure, and muscular tension, drop below baseline levels. Currently, research is indicating that the physical act of laughing, laughter's physiologic effects, even without humor, is linked to chemical changes in the body that potentially reduce stress [47]. Laughter can alter dopamine and serotonin activity. Furthermore, endorphins secreted by laughter can help when people are stressed or uncomfortable in a depressed mood. Laughter therapy is a noninvasive and non-pharmacological alternative treatment for stress and depression [48].

8) Furthermore, research shows that people with hobbies are less likely to suffer from stress. Activities that get people out and about can make them feel happier and more relaxed. This may be another interesting and essential part of balancing out the stress people experience [49].

\section{Annexe 2: Questionnaires}

\section{Demographic Data Questionnaire}

1) Please create an anonymous username (to compare the results before and after the health campaign): 
2) Year of birth:

3) Gender: O Male O female

4) Height $(\mathrm{cm}): \ldots \ldots \ldots$

5) Weight: .............

6) Civil status: O Single O Married O Divorced

7) Education level: O Elementary school

O High School/Apprenticeship O College/University

8) At UEFA since:

9) Employment: O Full time O Part-time

\section{Stress Scale Questionnaire}

DASS (Depression, Anxiety, Stress, Scale) is an international scientific recognized self-report scale designed to measure the negative emotional state of depression, anxiety and stress composed by a 42 -item questionnaire. It was created on a sample of 2914 Australian adults in 1995.

In the present UEFA study, stress is the only concern, hence, the DASS questionnaire is shortened by disregarding the anxiety and depression parts. The stress scale (items) is sensitive to levels of chronic non-specific arousal. It assesses difficulty relaxing, nervous arousal, and being easily upset/agitated, irritable/over-reactive and impatient.

Please read each statement and select the answer that indicates how much the statement applied to you over the past 7 days. There are no right or wrong answers. Do not spend too much time on any statement, but please answer each question.

\section{The Rating Scale Is as Follows}

O Not at all-NEVER

1) At some degree, or some of the time-SOMETIMES

2) At a considerable degree, or a good part of time-OFTEN

3) Very much, or most of the time-ALMOST ALWAYS

\section{Questionnaire Stress Perception (Pre-Test and Post-Test)}

1) I found myself getting upset by quite trivial things.

$\mathrm{O}$ never $\mathrm{O}$ sometimes $\mathrm{O}$ often $\mathrm{O}$ almost always

2) I tended to overreact situations

O never O sometimes O often O almost always

3) I found it difficult to relax and switch off work

O never O sometimes O often $\mathrm{O}$ almost always

4) I felt myself getting upset rather easily

O never O sometimes O often $\mathrm{O}$ almost always

5) I felt that I was using a lot of nervous energy

O never O sometimes O often O almost always

6) I found myself getting impatient when I was delayed in any way (e.g., lifts, 
traffic lights, being kept waiting)

$\mathrm{O}$ never $\mathrm{O}$ sometimes $\mathrm{O}$ often $\mathrm{O}$ almost always

7) I felt that I was rather touchy

O never O sometimes $\mathrm{O}$ often $\mathrm{O}$ almost always

8) I found it hard to wind down

O never O sometimes $\mathrm{O}$ often $\mathrm{O}$ almost always

9) I found that I was very irritable

O never O sometimes $\mathrm{O}$ often $\mathrm{O}$ almost always

10) I found it hard to calm down after something upset me

$\mathrm{O}$ never $\mathrm{O}$ sometimes $\mathrm{O}$ often $\mathrm{O}$ almost always

11) I found it difficult to tolerate interruptions to what I was doing

$\mathrm{O}$ never $\mathrm{O}$ sometimes $\mathrm{O}$ often $\mathrm{O}$ almost always

12) I was in a state of nervous tension

$\mathrm{O}$ never $\mathrm{O}$ sometimes $\mathrm{O}$ often $\mathrm{O}$ almost always

13) I was intolerant of anything that kept me from getting on with what I was doing

$\mathrm{O}$ never $\mathrm{O}$ sometimes $\mathrm{O}$ often $\mathrm{O}$ almost always

14) I found myself agitated

O never $\mathrm{O}$ sometimes $\mathrm{O}$ often $\mathrm{O}$ almost always

\section{Working/Job Conditions Questionnaire (Only Pretest)}

Likert scale is a psychometric scale commonly involved in research that employs questionnaires to measure attitudes or opinions. It is the most widely used approach to scaling responses in survey research. With this scale, respondents are asked to rate items on a level of five agreements: Strongly agree; Agree; Neutral (neither agree/nor disagree); Disagree; Strongly disagree.

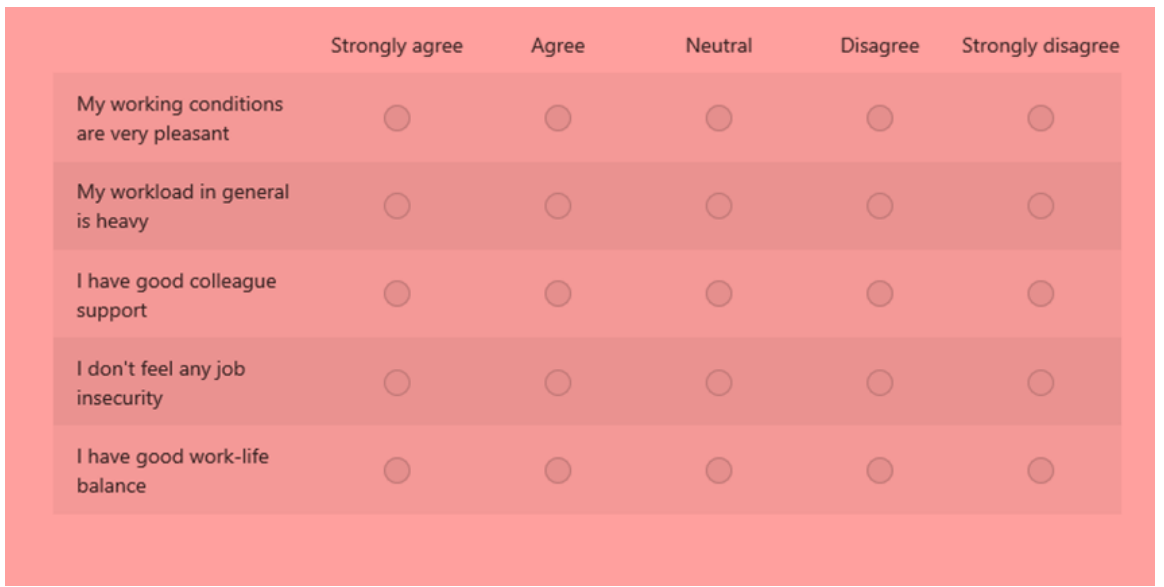

